\title{
Discharge and pressure relationship of sprinkler in open field
}

\author{
R. A. Pachore and S. S. Deshpande
}

Received : 14.01.2019; Revised : 21.02.2019; Accepted : 12.03 .2019

See end of the Paper for authors' affiliation

Correspondence to :

\section{R.A. Pachore}

Department of Irrigation and Drainage Engineering, K.K.Wagh College of Agricultural Engineering and Technology, Nashik (M.S.) India

Email : rahulpachore07 @ gmail.com
ABSTRACT : Irrigation generally is defined as the application of water to the soil for the purpose of supplying moisture essential for plant growth by making favourable environment for plant growth, to reduce the hazards of soil piping and to soften tillage pans. In India, generally traditional flood irrigation methods (basin, border and furrow) are used to irrigate crops, where in the entire soil surface is almost flooded without considering the actual consumptive requirements of the crops. These practices have created the problems of water logging and salinity and reduction in the overall irrigation efficiency hardly upto 30 per cent. An experiment will conduct on the Instructional Farm of Department of Irrigation and Drainage Engineering, K. K. Wagh College of Agricultural Engineering and Technology Nashik. It is revealed that minimum discharge of $39.61 \mathrm{ph}$ was recorded for green sprinkler for operating pressure of $1.0 \mathrm{~kg} / \mathrm{cm}^{2}$ and maximum discharge of $248.41 \mathrm{ph}$ was recorded for yellow sprinkler for operating pressure of $2.5 \mathrm{~kg} / \mathrm{cm}^{2}$, the radius of throw increases from 1.85 to $2.33 \mathrm{~m}, 2.50$ to $3.37 \mathrm{~m}$ and 3.55 to $4.49 \mathrm{~m}$ for green, red and yellow sprinklers, respectively. Co-efficient of uniformity is found to be best for green sprinkler at 87.23 per cent and other having 86.57 per cent and 58.52 per cent for yellow and red, respectively.

- KEY WORDS : Irrigation, Mini sprinkler, Discharge, Radius of throw, Co-efficient of uniformity

- HOW TO CITE THIS PAPER : Pachore, R.A. and Deshpande, S.S. (2019). Discharge and pressure relationship of sprinkler in open field. Internat. J. Agric. Engg., 12(1) : 118-123, DOI: 10.15740/ HAS/IJAE/12.1/118-123. Copyright@2019: Hind Agri-Horticultural Society. 